\title{
Medicinal plants used against typhoid fever and toothache in Pir-Panchal Range of the Shopian district of Kashmir Himalaya
}

\author{
Sumer Singh, Khanday Zakir Hussain* \\ Department of Botany, School of Life Science, Singhania University, Jhunjhunu, Rajasthan, India
}

Received: 08.02.2017
Accepted: 01.03.2017
Published: 05.03.2017
*Address for
correspondence:
Khanday Zakir Hussain,
School of Life Science,
Singhania University,
Jhunjhunu, Rajasthan, India.
E-mail: zkhanday@gmail.
com

\begin{abstract}
The current study was undertaken with a view to explore the possibilities of utilizing the plant resources of the district Shopian. A total of plants/specimens along with detailed information and their uses would serve as a valuable record for future reference and study. Most of these plants are wild and some plants are cultivated. The current study reveals that 22 medicinal plants belonging to 14 families are being used for treating typhoid fever and toothache in the Shopian district of Kashmir Himalaya. Of these 22 medicinal plants, 5 plant species are used both for treating fever and toothache. These medicinal plants have been arranged alphabetically. Despite the extensive use of medicinal plants by the people of this region, extensive work has not been done yet on ethnomedicinal and other aspects. The current study is an effort to promote a realm among the people regarding the possibility of natural alternatives in preventing typhoid fever and tooth diseases in the study area.
\end{abstract}

KEY WORDS: Himalaya, medicinal plants, Shopian, toothache, typhoid

\section{INTRODUCTION}

From ancient days, plants are used for habitat, food, and medicine. The use of plants for medicinal valve is as old as our culture. The first known record of remedial plants was Sumerian herbal of 2200 in the $5^{\text {th }}$ century BC. The Greek doctor Hippocrates lists out some 400 herbs of common use. In AD 77, the Greek surgeon Dioscorides published "De Materia Medica" plants, which are used particularly for their medicinal value. This descriptive medical book on medicinal plant treatment contained data on how and when each plant was accumulated, even if it was poisonous or not or it was edible or not. He highlighted the economic efficacy of plants. For long periods, herbs have been used for various times for several purposes such as healing the sick and ailing. Most of the herbs keep the body in harmony with nature and maintain proper balance. Human has always been conscious of the effects of plants on the body, mind, and feelings. For example, fragment plants were used to cure the body and give a scene of prosperity. The most precious flowers are accorded to Gods, and use of aromatic odor is recorded from a long times. Human has undoubtedly always been concerned with the question of health and survival and has sought within the framework of his knowledge and solution to the problems of illness.

The WHO has recognized the role of traditional system of medicine and considered them a part of strategy to provide health care to the masses. The need for medicinal plant-based raw material is increasing annually worldwide. International market size for herbal and medicinal plants is estimated at US $\$ 60$ billion and is featured to reach US $5 \$$ Trillion by 2050 (WHO, 2002). About $75-80 \%$ of the total exports of raw drugs came from India (Malik et al, 2011). India is the home of about 17,000 species of plants, out of which 7500 are known for their therapeutic uses. Ayurveda has reported about 2000 medicinal plant species, followed by Siddha and Unani. The "Charak Samhita," and ancient written document with rich literature regarding herbal therapy, describes the production of around 340 herbal drugs and their native use for treating various problems and diseases. 


\section{MATERIALS AND METHODS}

\section{Location and Study Area}

District Shopian is situated on the latitude of $33^{\circ}, 44 \mathrm{~N}$ and Longitude of 74, $50 \mathrm{E}$. It lies on the southwest of Kashmir. It is at one time called as "Shen-e-vann" meaning "Forest of Snow." Shopian is commonly known as the apple bowl of Kashmir. The district is at a distance of $50 \mathrm{~km}$ from the state capital Srinagar. Beset with considerable topographic, altitudinal climatic variation, it depicts a great habitat diversity and harbors a rich flora. The district is mainly agrarian, and most of the plants grow luxuriantly as weeds in waste lands, fallow lands, cultivated fields, etc (Raza et al, 1978).

\section{Methods}

Frequent field trips and ethnomedicinal surveys of the selected areas of Shopian, Keller, Zainapora tehsils of Shopian district of Jammu and Kashmir were undertaken during 2015-2016 as per the guidelines suggested by Schultes (1962), Jain (1967). The information about the use of plants as medicine and folklore was recorded by personal interviews with tribals (Gujjars and Bakarwals), Paharis, shepherds (chopans), and old experienced villagers under study. An inventory of plants and plant products used by the people of rural and tribal areas in their day-to-day life was prepared. Almost all the plants were collected in different seasons with the help of tribal and rural people. Parts of the plants used in the treatment of various problems and other related information were recorded. The information of plants was written in the field book. The data obtained from different localities, pertaining to local medicinally important plants, were carefully recorded. The information collected from the local people was further verified and checked by some knowledgeable person of the study area. Every such plant was studied for its identification. The chemical constituents written for each species of plant in the enumeration have been taken from the Glossary of Indian medicinal plants (Chopra et al, 1956).

\section{RESULTS}

The present study reported that 22 ethnomedicinal plant species belonging to 14 families are being used in the treatment of typhoid fever and toothache. The botanical

Table 1: Medicinal plants of Shopian district of Jammu and Kashmir used to cure typhoid fever and toothache

\begin{tabular}{|c|c|c|c|c|c|c|}
\hline S. No. & Botanical name & Family & Local name & Chemical constituents & Part used & Ethnomedicinal use \\
\hline 1 & Achillea millefolium $\mathrm{L}$. & Asteraceae & Pahel-gass & Achilleine, azulenes, coline & Whole plant & Toothache, fever \\
\hline 2 & $\begin{array}{l}\text { Aconitum heterophyllum wall. Ex } \\
\text { Royle }\end{array}$ & Ranunculaceae & Patis & $\begin{array}{l}\text { Heterastine, heterophylline, } \\
\text { atisine, atidine, hetidine }\end{array}$ & Root & Toothache, high fever \\
\hline 3 & Arnebia benthamii (wall.) Johnston & Boraginaceae & Khazaban & Dry plant yields essential oil & Leaves & High fever \\
\hline 4 & Artemisia absinthium L. & Asteraceae & Tethwen & $\begin{array}{l}\text { Sesquiterpene lactone, } \\
\text { artabsinarabsin }\end{array}$ & Whole plant & Various fevers \\
\hline 5 & Cichorium intybus L. & Liliaceae & Handiposh & Cichorin, lactucin, intybin & Root & Typhoid \\
\hline 6 & Datura stramonium L. & Solanaceae & Datur & $\begin{array}{l}\text { Flavonoids, coumarins, } \\
\text { tannins }\end{array}$ & Seeds leaves & Dental caries \\
\hline 7 & Delphinium denudatum & Ranunculaceae & Mori & & Root, flower & High fever, toothache \\
\hline 8 & Delphinium roylei Munz. & Ranunculaceae & Mameri & & Root & Tooth cavity pain \\
\hline 9 & Juglans regia L. & Juglandaceae & Doon & $\begin{array}{l}\text { Globulin (cysteine and } \\
\text { tryptophan) }\end{array}$ & Root bark & $\begin{array}{l}\text { Tooth infections, } \\
\text { cleaning of Teeth }\end{array}$ \\
\hline 10 & Nepeta cataria L. & Lamiaceae & Gandsoi & Volatile oil and Tannin & $\begin{array}{l}\text { Whole plant, } \\
\text { leaf }\end{array}$ & High fever \\
\hline 11 & Origanum vulgare $\mathrm{L}$. & Lamiaceae & Mazren & $\begin{array}{l}\text { Volatile oil, tannins, resin, } \\
\text { sterols, and flavonoids }\end{array}$ & Aerial part & Toothache \\
\hline 12 & Plantago major L. & Plantaginaceae & Logout gul & Glucosides, saponins & Seed, leaf & Fever and toothache \\
\hline 13 & Polygonum hydropiper $\mathrm{L}$. & Polygonaceae & Marchwangangass & $\begin{array}{l}\text { Essential oil, oxymethyl } \\
\text { anthraquinones }\end{array}$ & Leaves & Toothache \\
\hline 14 & Potentilla fruticosa L. & Rosaceae & Banchai & & Leaves & High fever \\
\hline 15 & Potentilla nepalensis Hook. & Rosaceae & Panzpater & - & Leaves, root & High fever \\
\hline 16 & Prunella vulgaris L. & Lamiaceae & Kal-weth & Essential oil & Flower & High fever \\
\hline 17 & Rhododendron campanulatum D. Don & Ericaceae & Wan-nas & Andromedotoxin & Leaves, flower & Fever, toothache \\
\hline 18 & Salvia moorcroftiana Wall. ex. Benth & Lamiaceae & Shrematus & Essential oil, mucil & Root & High fever \\
\hline 19 & Salix babylonica L. & Salicaceae & Veer & Salicin & Twig & $\begin{array}{l}\text { Weak gums, cleaning } \\
\text { of teeth }\end{array}$ \\
\hline 20 & Sonchus asper L. & Asteraceae & Dudh-kandij & $\begin{array}{l}\text { A and B lactucerols, } \\
\text { cerylalcohol, and mannitol }\end{array}$ & Aerial part & Fever \\
\hline 21 & Taxus baccata L. & Taxaceae & Posthal & Taxine & Leaf & High fever \\
\hline 22 & Viola biflora L. & Violaceae & Banfsha & - & Leaf extract & High fever \\
\hline
\end{tabular}


name, family, local name, chemical constituents, parts used, and ethnomedicinal uses of these medicinal plants have been compiled and shown in Table 1 .

\section{DISCUSSION}

Specifically, the Shopian district of Kashmir Himalaya harbors a good proportion of endemic as well as nonendemic flora; based on its endemicity and unique geography, it has attracted the attention of explorers and botanists from the time when journey was most tedious and quite unsafe. The purpose of the current investigation is to explore the flora of this floristically rich area with a special emphasis on gathering information from the tribals and rural people living in the forest areas pertaining to ethnobotanical uses of plants, which are so bountiful in their ambience. Especially the rural people and the tribals of this selected area depend on the surrounding forests for almost everything. They prefer to use their folk medicines practiced by their elderly persons who enriched their knowledge by long experience. According to informants, they are capable of healing and curing various diseases with home medicines.

\section{CONCLUSION}

The study area is very rich both floristically and ethnomedicinally. Further research is required on the phytochemistry of such plants which are effective in the treatment of a particular disease. Moreover, the study has brought to some useful medicinal plants which are subjected to pharmacological and clinical trials on experimental animals, and if found efficacious, they can be recommended for human use. For this purpose, it would be better if the active ingredient or active principle is isolated by further researches so that more effective use of these plants may be made.

\section{ACKNOWLEDGMENT}

The authors are thankful to Dr. Iqbalchak and Dr. Firdoous Ahmad Mir (Scientist NISCAIR) for helping in identification of plants. Thanks to the people of the study area whom we consulted during the course of field observation.

\section{REFERENCES}

Chopra RN, Nayar SL, Chopra IC. Glossary of Indian Medicinal Plants. New Delhi: CSIR; 1956.

Jain SK. Ethnobotany: Its scope and study. Indian Mus Bull 1967;2:39-43.

Malik AR, Siddique MM, Sofi PA, Butola JS. Ethnomedicinal practices and conservation status of medicinal plants of North Kashmir Himalayas. Res J Med Plants 2011;5:1-15.

Raza MA, Mohammad A.The Valley of Kashmir a Geographical Interpretations. Vol. 1. New Delhi: The Land Vikas Publishing House Ltd.; 1978.

Schultes RE. The role of ethnobotanist in the search for new medicinal plants. Lloydia 1962;24:257-65.

WHO. World Health Organization Traditional Medicine Strategy: 2002-2005. Geneva:WHO; 2002. p. 11. 